\title{
Influence of Ethical Position and Information Asymmetry on Transfer Price Negotiations
}

\author{
Karen Green ${ }^{1}$, Doctoral Candidate \& Benson Wier ${ }^{1}$, Professor \\ ${ }^{1}$ Department of Accounting, Virginia Commonwealth University, USA \\ Correspondence: Karen Green, Doctoral Candidate, Department of Accounting, Virginia Commonwealth University, \\ USA. E-mail: greenky@vcu.edu \\ Received: October 15, 2014 \\ Accepted: November 30, 2014 \\ Online Published: December 2, 2014 \\ doi:10.5430/afr.v4n1p30 \\ URL: http://dx.doi.org/10.5430/afr.v4n1p30
}

\begin{abstract}
This study examines the potential effect of ethical position (EP) on negotiation strategies and behaviors in an intra-firm setting. We demonstrate that EP moderates the relationship between information asymmetry and the initial transfer price during negotiations for individuals who are morally situational. Graduate business students participated in an experiment that randomized the level of information they could use in determining their initial asking price and their reservation price in a negotiation. This manipulation allows us to examine managements' negotiation behavior when making an ethical judgment. Further, we relate their transfer price position to their EP that consists of two orthogonal factors, relativism and idealism. We find that access to the opposing division's private information does not influence the initial transfer price position of those who are relatively idealistic. Contrary to our hypothesis, these results suggest that during transfer price negotiations, those who are more relativistic will have a smaller initial transfer price dispersion than those who are relatively idealistic. This study provides evidence that EP plays an important role in transfer price negotiation behaviors.
\end{abstract}

Keywords: Ethical position, Negotiation, Reservation price, Transfer price

\section{Introduction}

Negotiations consist of offers and counter offers resulting in managers seeking to extract maximum rents. Negotiations are common in many professions. Managers within the same organization often negotiate prices to exchange goods or services. This practice is referred to as transfer price negotiation or intra-firm trade. When both divisions are profit centers responsible for revenues and costs, the transfer price represents a revenue source for the selling division while it is a cost for the buying division. Therefore, the transfer price selected will affect the net profit for both divisions and can create conflict between managers (Eccles, 1985).Traditionally, transfer price negotiations are viewed as an individual behavioral and organizational issue. Individual and organizational factors affecting transfer price negotiations identified in previous research include the negotiation process (e.g., Ghee-Soon Lim \& Murnighan 1994; Thompson and Lowenstein 1992), perceived fairness (e.g., Chang, Cheng, and McGinn 2008; Kachelmeier and Towry 2000; Luft and Libby 1997), multinational tax (e.g., Autrey and Bova 2012; Dembinski, 2006), and transfer price method comparisons (e.g., Pfeiffer, Schiller, and Wagner 2011;Baldenius 2000; Baldenius, Reichelstein and Sahay 1996).

Transfer price negotiations are also considered an ethical issue. In the agency theoretic view, a manager will shirk organizational responsibilities and seek a transfer price that favors their division (Edlin and Reichelstein 1995). Because the magnitude of the initial transfer price has consequences for others, transfer price negotiations create an ethical dilemma. Despite the questionable ethics that occur in business practice(Neale and Baserman 1991; Pruitt 1981), studies that include interviews (Eccles 1985), surveys (Davis, Andersen, and Curtis 2001; Douglas and Wier 2000), and behavioral experiments (Douglas, Davidson, and Schwartz 2001) indicate that this behavior is a common. Furthermore, Bok (1978) finds that in the negotiation settings, such as a transfer price negotiation setting, embellishing is an expected and common behavior. These observations call for the primary research question: Does ethical position (EP) explain managers' propensity to maximize their initial transfer price position during transfer price negotiations?

EP consists of two constructs: relativism and idealism. Those who are more idealistic believe in absolute moral rules and are prone to view a decision as ethical if the results have positive consequences for all parties affected by the 
decision. Those who are more relativistic do not rely on universal absolute moral rules. However, they will analyze circumstances surrounding each situation to determine the appropriate ethical judgment (Forsyth and Pope 1984; Forsyth 1980; 1981).

The initial transfer price position influences the outcome of transfer price negotiations. Anchoring and adjusting theory (Einhorn and Hogarth 1981) provides a theoretical framework that suggests that during intra-firm negotiations managers are affected by the initial asking price (Bazerman and Moore 2009). Further, Ritov (1996) provides empirical evidence that amount stated for the initial asking price during a negotiation is positively correlated with the agreed upon final price. Thus, the initial transfer price provides important information for the negotiation process.

The information available is considered because in negotiating settings, varying levels of information available influences decision-making (Fisher, Fredrickson, and Peffer, 2002). By examining how managers use private information, we are able to examine the ethical component in transfer price negotiations. This study uses terms from Stevens (2002) to differentiate the amount of information a manager has during the transfer price negotiation. Partial information asymmetry refers to the situation in which the manager possesses their opponent's private information. In addition, the opponent only has access to his or her own information. Further, the term full information asymmetry refers to the situation in which neither party possesses information regarding the other party.

Consistent with Douglas and Wier (2000), our results suggest that an individual's underlying EP also affects managers' initial transfer price position during intra-firm negotiations. The availability of the opposing divisions' private information, or partial information asymmetry, does not influence the initial transfer price position for relatively idealistic managers. However, contrary to expected behavior, more relativistic managers decrease their initial transfer price dispersion. These managers use the distortion created by partial information asymmetry by simultaneously decreasing their initial transfer asking price and increasing their reservation price.

This study contributes to transfer price negotiations and ethics literature by examining the influence of EP on management behaviors in a negotiation setting. The interaction and main effects between EP and level of information asymmetry suggests that EP does play an important role in transfer price negotiation behaviors. Exaggeration during negotiations is common practice (Carr 1968; Bok 1978) and is time-consuming (Fudenberg and Tirole 1983; Pruitt 1981). Bluffing in transfer price negotiations diverts manager's efforts from value added activities caused by the increase time necessary for negotiation concessions. For instance, Eccles (1985) provides anecdotal evidence that half of managers' time during their first three months in a firm is dedicated to transfer price negotiations. Consequentially, by increasing understanding manager behaviors during transfer price negotiations, firms may be able to mitigate the excessive time commitment caused by numerous concessions during transfer price negotiations.

The remainder of this paper is organized as follows. The second section consists of the background and hypotheses development, while the third section outlines the method used. We describe the results in the fourth section, and conclude with the discussion, future research, and limitations in the fifth section.

\section{Literature Review and Hypotheses}

\subsection{Transfer price negotiation}

A transfer price is the price of the product or service resulting from an intra-firm trade. When the divisions are participating in the trade are profit centers, the transfer price becomes the selling divisions' revenue and the buying divisions' cost, thus creating opposing objectives during a transfer price negotiation. However, this conflict can provide benefits to the organization in that a manager may divulge information to not only the firm but also to the other manager in order to obtain a desired price (Ghosh 2000; Eccles 1985). Further negotiating transfer prices allow the perseverance of autonomy within divisions and provide motivation to managers to increase their division's operating income (Horngren, Datar, and Foster 2011).

Prior studies have examined the relationship among psychological variables at the individual behavioral level in transfer price negotiation. Luft and Libby (1997) provide support of the influence market prices and accounting data has on transfer price negotiations and the perceived fairness of the outcome. In addition, they find that unfair profit comparisons influence managers' judgments during negotiations. Kachelmeier and Towry (2002) examine social behavior in transfer price negotiations. They find evidence that in-person negotiations with unrestricted communication are more likely to result in a fairer outcome than negotiations that occur over a computer network. Chang et al. (2008) extends both studies to include framing effects of the negotiator position, buyer versus seller. They find that when a partner encourages divisions to divide profits equally, managers are more willing to accept a lower price. 
In the agency theoretic view, managers will shirk responsibility to their organization and behave in a self-satisfying manner (Eisenhardt 1989). Harrell and Harrison (1994), and Douglas and Wier (2000) argue shirking will occur when the opportunity is present and an incentive exists. In addition, extant scholarship suggests that incentives are present in transfer price negotiations. Managers' compensation is typically linked to their division's performance (Eccles 1985) and managers will request a transfer price that maximizes their division's net profit as opposed to bidding a transfer price that is optimal to the organization (Edlin and Reichelstein 1995). Thus, prior literature and theory suggest that managers have incentives when transfer price negotiations are concerned.

Negotiators tend to believe that their opponent's asking price is in the best interest of the opposing division (Neale and Baserman 1991). To offset this perceived unfairness, managers will request a transfer price that diverges from their reservation price. This practice is known as bluffing (Carr, 1968) or their initial transfer price dispersion. Both parties rationalize their exaggeration with the expectation that the other party will also embellish (Bok, 1978), resulting in an initial transfer price dispersion that may not benefit the firm. Accordingly, transfer price negotiations create an ethical dilemma such that the initial transfer price position has consequences for others.

\subsection{Ethics}

The traditional behavioral view of transfer price negotiation does not consider the ethical component of managers' decision- making. Douglas and Wier (2000)argue that in the business context, ethical judgment involves individuals first determining whether an action is ethical and then deciding whether to participate. Thus, during an intra-firm negotiation consideration of managers' ethical judgments is necessary. Forsyth (1980) determines that ethical judgments are based on individuals' EP and classifies individuals through their underlying ethical values based on two beliefs: (1) acceptance or rejection of universal absolutes moral rules and (2) the belief a decision is deemed ethical ifgood consequences result for all parties affected, as opposed to acknowledging that outcomes are a combination of good and bad consequences (Forsyth and Pope 1984; Forsyth, 1980; 1981).

$\mathrm{EP}$ is a latent construct based on idealism and relativism. An individual is considered relatively idealistic when faced with a moral decision they rely on universal moral absolute rules (Douglas et al., 2001). Additionally, when confronted with an ethical dilemma they will consider the possible harm to all parties affected because of their "focus on human welfare" (Greenfield et al., 2008, p. 420).Yet individuals who do not rely on universal absolute rules when making moral judgments and believe that a decision can be ethical while consisting of a combination of good and bad consequences, are considered more relativistic. This results in ethical judgments that generate negative consequences for other parties involved.

Prior research validates EP in accounting research. Douglas and Wier (2000) surveyed management accountants and find evidence that EP, information asymmetry, and incentives influence budgetary slack creation. Further, they provide support that managers who are relatively idealistic exhibit less slack creation behaviors while those who are more relativistic increase slack. Douglas et al. (2001) examine factors that influence ethical judgments of CPAs. Through an experimental study, they provide evidence that corporate culture coupled with strong organizational rules influence ethical decisions of relatively idealistic CPAs. In addition, Greenfield et al. (2008) associate EP with earnings management behavior. Specifically, they find managers who are more relativistic respond to situations in a manner that increases their personal benefit. Therefore, given that relativistic managers tend to create larger budgetary slack (Douglas and Wier 2000) to improve their situation (Greenfield et al. 2008), we expect that relativistic managers will select an initial transfer price position that is large in order to benefit their negotiations. On the other hand, because managers who are more idealistic are found to behave less opportunistically than their relativistic counterpart (Douglas and Wier 2000), we predict that idealistic managers will have a smaller transfer price dispersions. As discussed in these prior studies, theory and evidence provide support that EP will affect ethical behaviors. Based on these arguments, $\mathrm{H} 1$ is:

H1: Managers who are more relativistic will have a greater initial transfer price position than that of managers who are more idealistic.

\subsection{Information asymmetry}

During transfer price negotiations, managers must make decisions with asymmetric information. Ideally, a desired transfer price would be one that benefits both divisions and the corporation. For this to occur both parties need to share private information (Pruitt 1981). However, unless disclosing private information benefits their own division, managers are hesitant to divulge information in order to maintain a competitive advantage (Neale and Baserman 1991). 
Extant scholarship has examined the effects of information asymmetry on negotiation behaviors at the individual and organizational level. Fisher, Fredrickson, and Peffer (2002) provide evidence that information asymmetry influences the initial asking price during budget negotiations. Specifically, they find that when information asymmetry is present, managers' initial positions are affected. Kennan and Wilson (1993) in a meta-analysis of empirical studies on negotiation behaviors, find that knowledge of the opponent's reservation price influences the negotiation process because fewer assumptions are necessary.

Edlin and Reichelstein (1995) examine transfer price negotiations with incomplete information and find that to achieve an efficient price, re-negotiations must occur as new facts become available. Based on bargaining theory, they demonstrate that information asymmetry will result in a transfer price outcome that is not only perceived as unfair, but also inefficient. Based on game theory, Rubinstein (1991) provides support that when negotiations occur under incomplete information, the price is dependent on manager's view of their opponent's payoff. Thompson and Lowenstein (1992, p.177) argue that egocentrism influences negotiators perception of fairness. Especially in ambiguous situations, such as in the presence of information asymmetry, the negotiator "... will be biased in a manner that favors themselves." Therefore, when information asymmetry exists, egocentrism will bias manager's perception of fairness and result in a change in their initial transfer price dispersion.

Based on prior literature and theory, managers who have relativistic tendencies will use their opponent's private information to their advantage. Because relativistic managers' ethical view is circumstantial, they adjust their initial transfer price when privy to their opponent's information. However, managers who are more idealistic are less likely to use information in their favor to improve their position (Greenfield et al. 2008). Hence, in a negotiation-setting, due to their underlying beliefs to consider the welfare of all parties affected, more idealistic managers will not adjust their initial transfer price when their opponent's private information is available. H2 suggests the following relationships:

\section{H2A(B): As relativism (idealism) increases, the initial transfer price position will increase (not change) when partial information asymmetry is present.}

\section{Research Methodology}

We used a survey instrument to solicit respondents' initial transfer asking price and reservation price. The materials consisted of an anonymous, self-administered questionnaire that contains a case, case question, manipulation checks, EP assessment items, and followed by demographic questions. Demographic variables included program of study, age, gender, job position, and experience. Next, we describe the sample of respondents, the contents of the research instrument, and how the variables are used.

\subsection{Sample selection}

Participants consist of graduate business students from a large mid-Atlantic University. Given their knowledge and work experience, graduate students are valid surrogates for managers for this task (Libby, Bloomfield, and Nelson 2002).The students received classroom instruction on transfer pricing prior to the experiment. However, Luft and Libby (1997) state that student participation in a transfer price negotiation experiment may have implications on the study. Students may have an inability to understand the consequences market prices has on transfer price negotiations. Considering this issue, the participants were told the market prices for similar products and they were informed that a transfer price set above the lowest market price would result in a loss to the firm. In regards to the generalizability of students' EP to professionals, Nasir, Sallem, and Othman (2012) compare EP of accounting students to accounting practitioners. They find no significant differences between the two groups' regarding EP.

Of the 98 graduate students surveyed, 12 failed the manipulation check questions, and three had a serious omission, resulting in $85(86.7 \%)$ useable responses. The average age of the participants is 29 years and $45 \%$ are female. They have an average of 6 years work experience, $71 \%$ are employed full time, $19 \%$ are employed part-time, and $10 \%$ are unemployed. In addition, $8 \%$ have participated in transfer price negotiations in their employment. The analysis excludes participants' responses that failed the manipulation checks or had serious omissions. Table 1 illustrates the participants' demographic profile. 
Table 1. Demographics profile

\begin{tabular}{|c|c|c|c|}
\hline Female & $45 \%$ & Employment Experi & ence: \\
\hline Male & $55 \%$ & $\begin{array}{l}\text { Financial } \\
\text { Accounting }\end{array}$ & $24.70 \%$ \\
\hline $\begin{array}{l}\text { Average } \\
\text { Experience }\end{array}$ & 6 years & Service & $44.70 \%$ \\
\hline Employment Status: & & Manufacturing & $9.40 \%$ \\
\hline Full time & $71 \%$ & Government & $5.90 \%$ \\
\hline Part time & $19 \%$ & No Response & $9.40 \%$ \\
\hline Unemployed & $10 \%$ & Other & $5.90 \%$ \\
\hline
\end{tabular}

\subsection{Research instrument}

A 2 X 1 between-subjects experimental survey instrument asked participants to read a scenario in which two divisions are participating in an intra-firm sale. The participants assumed the role of the selling division manager and asked to place the initial asking price and state their reservation price during a transfer price negotiation for the sale of 3,000 speakers. The respondents were presented with an example of an intra-firm trade and a simple income statement that illustrates revenues and costs of the selling division for the sale of 10,000 speakers. Additionally the income statement presents the buying divisions' revenues and costs for the sale of 3,000 television sets. The objective of the income statement was to remind participants of the effects a transfer price has on both divisions.

The participants were requested to make several assumptions. The selling and the buying division can sell and buy the speakers externally, thus limiting the transfer price that would result in an overall profit by the parent company. In addition, the selling division has excess production and is producing within capacity, meaning that there is no opportunity cost associated with the internal transfer. Lastly, a range of prices were provided in which the parent firm would benefit from.

Using random assignment, some participants received only their possible net profits for each transfer price option for their selling division (full information asymmetry). While the other participants not only received their possible net profits for each transfer price option but also the corresponding net profits for the buying division(partial information asymmetry). The initial transfer price respondents could select include a range from a cost below the variable cost $(\$ 25)$ to a cost above the lowest market price (\$65). Participants also indicated their reservation price, the lowest price they are willing to accept.

EP scores are obtained through use of the validated Ethical Position Questionnaire (EPQ) developed by Forsyth (1980). The EPQ consists of 20 items (10 items for each dimension: relativism and idealism). Respondents were requested to evaluate their level of agreement for each item on a 9-point Likert scale. The 10 scores for relativism and idealism are each averaged yielding a relativist score and an idealist score for each participant. The reliability for relativism and idealism is assessed using Cronbach's alpha, which is 0.88 and 0.89 respectively.

Extant studies provide evidence that gender influences negotiation strategies. For instance, Bowled, Babcock, and McGuinn(2005), and Bear and Babcock (2012) find that women negotiate less well than males. Further, Quintelier and Fessler (2012) provide evidence that age influences moral relativism. Therefore, gender and age are included as covariates in the analysis. We considered common method bias when designing the study, and performed repeated pilot testing, assured the participants anonymity, and used multiple samples (Podsakoff, MacKenzie, and Lee 2003). In addition, the correlation illustrated on Table 2 indicates that the constructs, relativism and idealism are substantially correlated. This suggests that common method bias does not significantly influence responses.

Table 2. Correlation, Covariance and Variance Matrix

\begin{tabular}{llcc}
\hline & Relativism & Idealism & Information \\
\hline Relativism & 2.834 & & \\
Idealism & -0.056 & 2.047 & \\
Information & -0.023 & -0.041 & 0.253 \\
\hline
\end{tabular}




\section{Results}

Comparing means of the initial transfer price position, more relativistic respondents had a larger average (mean \$21.60; standard deviation 9.56) compared to those who are more idealistic (mean \$20.33; standard deviation. 9.10). Providing initial support for $\mathrm{H} 1$ that managers who are more relativistic will have a larger initial transfer price dispersion compared to those who are relatively idealistic (See Figure 1).

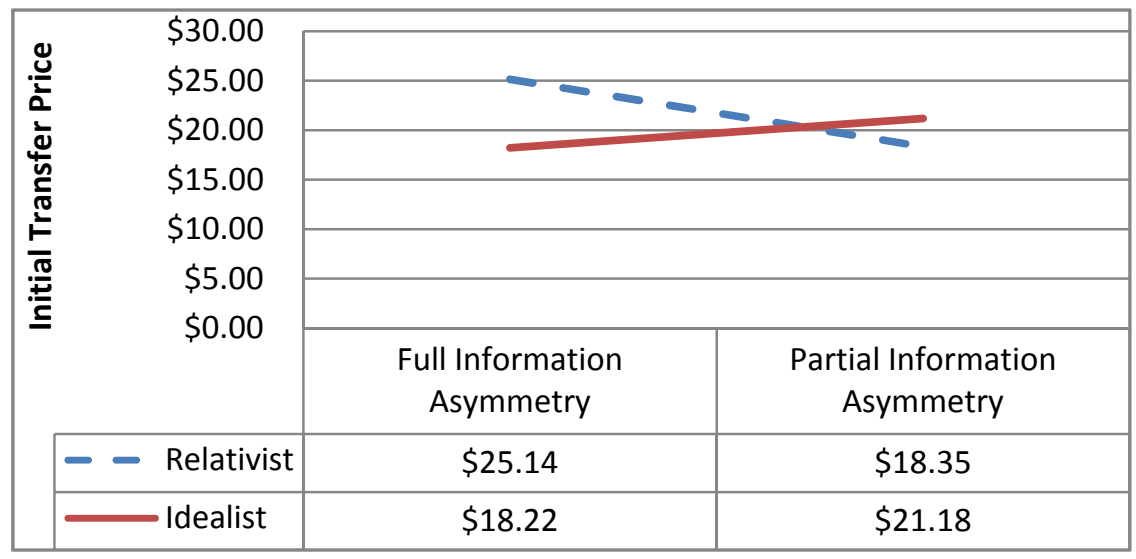

Figure 1. Interaction of Ethical Position Information Asymmetry

The hypotheses are tested using regression analysis. The difference between the initial transfer placed during the negotiation and the participant's reservation price is the dependent variable used to determine the initial transfer price position. The independent variables used to test the interactions and main effects include idealism, relativism, level of information, age, and gender.

4.1 Result for H1: Managers who are more relativistic will have a greater initial transfer price dispersion than that of managers who are relatively idealist.

The model from table 3 is overall significant $(F=3.34$, $p$-value $=0.004)$ and $R^{2}$ of 0.235 . The regression shows that IDEALIST is not significant ( $\mathrm{p}$-value $=0.868$ ), while RELATIVIST is statistically significant ( $\mathrm{p}$-value $=0.001$ ). This means that as idealism increases, the initial transfer price dispersion does not significantly change. However, as relativism increases, the initial transfer price position increases. Consistent with H1, managers who are more relativistic will have a larger initial transfer price dispersion than those who are relatively idealistic.

4.2 Result $H 2 A(B)$ : As relativism (idealism) increases, the initial transfer price position will increase (not change) when partial information asymmetry is present.

In the presence of partial information asymmetry, shown in table 3, INFORMATION X IDEALIST is not significant $(\mathrm{p}$-value $=0.649)$. This suggests that partial information asymmetry, or knowledge of opponent's prices, has no influence on relatively idealist's initial transfer price dispersion, supporting H2B. Participants with high relativist scores and partial information asymmetry (INFORMATION X RELATIVIST) is significant (p-value $=0.004$ ), however, not in the expected direction, failing to support H2A. The significant negative coefficient suggests that as relativism increases, the presence of opponent's private information results in a decrease of the initial transfer price dispersion. 
Table 3. Regression Analysis

Dependent

Variable: Initial

Transfer Price

Position

\begin{tabular}{lcccc} 
& $\begin{array}{c}\text { Unstandardized } \\
\text { Beta Coefficient }\end{array}$ & $\begin{array}{c}\text { Standard } \\
\text { Error }\end{array}$ & T-statistic & p-value \\
\cline { 2 - 5 } Relativism & 1.987 & 0.686 & 2.900 & 0.005 \\
Idealism & -0.175 & 0.891 & -0.200 & 0.845 \\
Information & 5.207 & 9.869 & 0.530 & 0.599 \\
Relativism*Information & -3.014 & 1.673 & -2.580 & 0.012 \\
Idealism*Information & 1.269 & 1.300 & 0.980 & 0.332 \\
Age & 0.002 & 0.120 & 0.010 & 0.990 \\
Gender & -4.039 & 1.894 & -2.130 & 0.036 \\
Constant & 14.904 & 7.679 & 1.940 & 0.056 \\
\hline $\mathrm{R}^{2}$ & & & & 0.171 \\
Adjusted $\mathrm{R}^{2}$ & & & & 0.097
\end{tabular}

Variable definitions:

Relativism: Average of respondent's relativism score

Idealism: Average of respondent's idealism score

Information: indicator variable 1 if partial asymmetry is present and 0 otherwise

Age: respondent's age

Gender: indicator variable 1 iffemale and 0 if male

To explain the significant negative interaction between partial asymmetry for more relativistic managers, we analyze Forsyth's EP dimensions by the components of the initial transfer price dispersion: the initial asking price and reservation price. Relativism and idealism scores are dichotomized by their respective medians to perform group comparison t-test. Table 4 indicates that when managers become aware of the other division's information, managers who are more relativistic have a marginally statistically significant decrease in their initial transfer asking price (t-test $\mathrm{p}$-value 0.096 ) and a marginally significant increase their reservation price ( $\mathrm{t}$-test $\mathrm{p}$-value $=0.100$ ). Thus, resulting in a statistically significant decrease of their initial transfer price dispersion (t-test $\mathrm{p}$-value $=0.014$ ). Indicating that more relativistic managers will use of the information provided from their opponent's private information and adjust their transfer price negotiation strategy.

Managers who are more idealistic have a marginally significant decrease in their initial transfer asking price (t-test $\mathrm{p}$-value $=0.070$ ). However, their reservation price does not significantly differ when partial information asymmetry is present versus full information asymmetry (t-test $\mathrm{p}$-value $=0.640$ ). In addition, the initial transfer price dispersion is not statistically significant (t-test $\mathrm{p}$-value $=0.624$ ). This means because an interaction is not present between information and transfer price dispersion for more idealistic managers, additional information does not affect their initial transfer price. 
Table 4. Group Comparison T-test: Information Asymmetry

Full Information Asymmetry Partial Information Asymmetry Two-tailed t-test p-value

\begin{tabular}{llll}
\hline Relativism & & & \\
Initial transfer price & 59.23 & 56.26 & 0.096 \\
Reservation price & 34.09 & 38.04 & 0.100 \\
Size dispersion & 25.14 & 18.22 & 0.014 \\
Idealism & & 56.10 & 0.070 \\
Initial transfer price & 58.73 & 36.50 & 0.640 \\
Reservation price & 37.73 & 19.60 & 0.624 \\
Size dispersion & 21.00 &
\end{tabular}

4.3 Additional analysis

Further examination is performed through analysis of Forsyth's EP dimensions in detail. Forsyth (1981) determined that when crossing the classifications of EP creates classification of high/low relativist and idealist scores. These are categorized into subgroups: situationists, absolutists, subjectivists, and exceptionists (See Figure 2) adopted from Forsyth (1980).

\begin{tabular}{|c|c|c|}
\hline & High Relativism & Low Relativism \\
\hline $\begin{array}{l}\text { High } \\
\text { Idealis } \\
\text { m }\end{array}$ & $\begin{array}{l}\text { Situationist } \\
\text { Those who analyze each moral } \\
\text { judgment within the context of } \\
\text { each situation }\end{array}$ & $\begin{array}{c}\text { Absolutist } \\
\text { Those who believe that an } \\
\text { absolute universal code of values } \\
\text { will have the best outcome }\end{array}$ \\
\hline $\begin{array}{c}\text { Low } \\
\text { Idealis } \\
\text { m }\end{array}$ & $\begin{array}{c}\text { Subjectivist } \\
\text { Those who use personal values / } \\
\text { perspectives as opposed to the a } \\
\text { universal code of values }\end{array}$ & $\begin{array}{c}\text { Exceptionist } \\
\text { Those who typically use an } \\
\text { absolute universal code of values; } \\
\text { However, they are open to } \\
\text { exceptions }\end{array}$ \\
\hline
\end{tabular}

Figure 2. Taxonomy of Ethical Position

We find that subjectivists decrease their initial transfer asking price (t-test $\mathrm{p}$-value 0.470 ), increase their reservation price $(\mathrm{t}$-test $\mathrm{p}$-value $=0.244)$, which results in the decrease of their initial transfer price dispersion $(\mathrm{t}$-test $\mathrm{p}$-value $=$ 0.168 ) when partial information asymmetry is present. However, these changes are not statistically significant (Table 5).

The other ethical dimensions that consist of individuals who are more relativistic are the situationists. As the level of information changes from full to partial information asymmetry, situationists significantly decrease their initial transfer price dispersion ( $\mathrm{t}$-test $\mathrm{p}$-value $=0.026$ ). This effect is driven by significant decrease of their initial transfer asking price (t-test $\mathrm{p}$-value $=0.004)$. While their reservation price increases but is not statistically significant ( $\mathrm{t}$-test p-value $=0.262$ ). According to Forsyth and Pope (1984), this is due to situationists strive for outcomes that have the best possible consequences however, they will apply morals differently across situations. 
Table 5. Ethical Position Dimension Averages and Group Comparison T-test

\begin{tabular}{|c|c|c|c|}
\hline & $\begin{array}{c}\text { Full Information } \\
\text { Asymmetry }\end{array}$ & $\begin{array}{l}\text { Partial Information } \\
\text { Asymmetry }\end{array}$ & $\begin{array}{l}\text { two-tailed t-test } \\
\text { p-value }\end{array}$ \\
\hline \multicolumn{4}{|l|}{ Subjectivist $(\mathrm{n}=23)$} \\
\hline Initial transfer price & 57.92 & 55.75 & 0.470 \\
\hline Reservation price & 34.62 & 37.92 & 0.244 \\
\hline $\begin{array}{l}\text { Initial Transfer Price } \\
\text { Position }\end{array}$ & 23.31 & 17.83 & 0.168 \\
\hline \multicolumn{4}{|l|}{ Situationist $(\mathrm{n}=24)$} \\
\hline Initial transfer price & 61.11 & 56.82 & 0.004 \\
\hline Reservation price & 33.33 & 38.18 & 0.262 \\
\hline $\begin{array}{l}\text { Initial Transfer Price } \\
\text { Position }\end{array}$ & 27.78 & 18.64 & 0.026 \\
\hline \multicolumn{4}{|l|}{ Absolutist $(\mathrm{n}=21)$} \\
\hline Initial transfer price & 57.08 & 55.22 & 0.436 \\
\hline Reservation price & 40.77 & 34.44 & 0.043 \\
\hline $\begin{array}{l}\text { Initial Transfer Price } \\
\text { Position }\end{array}$ & 16.31 & 20.78 & 0.231 \\
\hline \multicolumn{4}{|l|}{ Exceptionist $(\mathrm{n}=19)$} \\
\hline Initial transfer price & 57.00 & 57.55 & 0.685 \\
\hline Reservation price & 36.00 & 36.00 & 1.000 \\
\hline $\begin{array}{l}\text { Initial Transfer Price } \\
\text { Position }\end{array}$ & 21.00 & 21.55 & 0.874 \\
\hline
\end{tabular}

We speculate that with the availability of their opponent's information, situationists are knowledgeable of their opponent's consequences and they will adjust their initial transfer price to a price they perceive as reasonable to both parties. Indicating the overall significant negative decrease of the interaction between relativism and partial information asymmetry could be attributed to the decrease of situationists' initial transfer asking price. This behavior is illustrated in Figure 3.

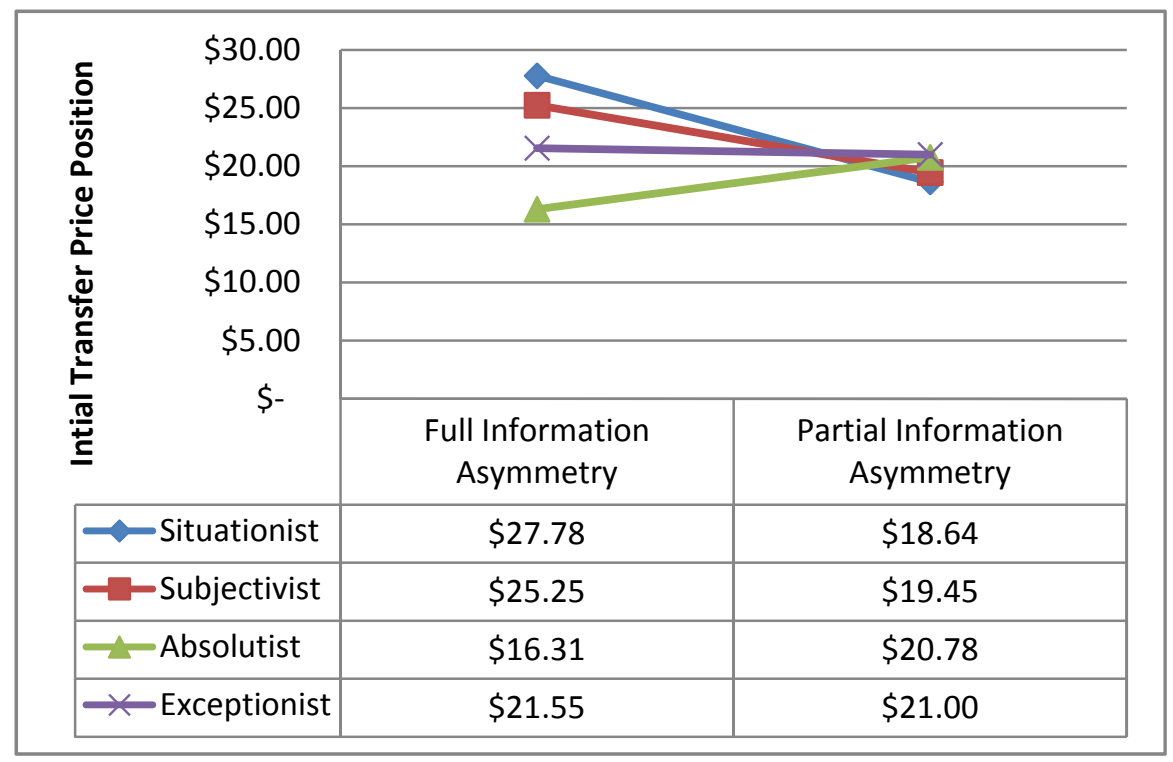

Figure 3. Dichotomized Ethical Position 
Exceptionists are considered utilitarian (Forsyth, 1981) meaning that their behavior is centered on the philosophy to choose an action that has positive consequences for the greatest number of parties (Donaldson and Wehane, 1996). These managers will use the information available to choose a transfer price that is in the best interest for the greatest number of stakeholders. When access to their opponent's net profit information, exceptionists do no alter their initial transfer asking price ( $\mathrm{t}$-test $\mathrm{p}$-value 0.685$)$, reservation price $(\mathrm{t}$-test $\mathrm{p}$-value $=1.000)$, or their initial transfer price dispersion ( $\mathrm{t}$-test $\mathrm{p}$-value $=0.874$ ). This suggests that absolutists will select a transfer price dispersion that has the best interest of both their division and their opponent's regardless of the level of information available.

We find that in the presence of partial asymmetry compared to full information asymmetry, absolutists do not alter their initial transfer price $(\mathrm{t}$-test $\mathrm{p}$-value $=0.436$ ) or their initial transfer dispersion ( $\mathrm{t}$-test $\mathrm{p}$-value $=0.231$ ). However, they decrease their reservation price from $\$ 40.77$ per speaker to $\$ 34.44$ per speaker (t-test $p$-value $=0.043$ ). This is attributed to their underlying universal rules and their desire to obtain good outcomes for all parties affected. With the availability of their opponent's prices, the absolutist managers are knowledgeable of potential consequences for both parties. Therefore, as long as the transfer price will benefit both divisions, the absolutists are willing to forgo excess revenue to increase the greater good for both divisions.

\section{Discussion, Future Research, and Limitations}

\subsection{Conclusions and recommendations}

We find support that when managers possess private information about their opponents' cost structure, managers who are more relativistic will have a larger initial transfer price dispersion than those who are relatively idealistic. When examining the interaction between information asymmetry and initial transfer price dispersion, an interaction is present between the information available and transfer price dispersion for managers who are more relativistic. Yet, opponent's private information does not affect the initial transfer price dispersion for those who are more idealistic. This means that ethical position affects manager's transfer price negotiations.

This study has broad implications for firms that use intra-firm negotiation. Based on these results, there is possibility that if firms were to place a limit on the initial transfer price during intra-firm negotiations then transfer price dispersion could be smaller. Anchoring and adjusting theory argues managers will select an initial transfer price and are resistant to deviate a great deal from that price. Thus capping the initial asking price would limit the negotiation range of transfer prices. The cap would limit the transfer price dispersion causing morally situational managers to adjust their transfer price dispersion towards that of the morally universal manager. This could result in fewer concessions during transfer price negotiations. Eccles (1985) provides evidence that when managers begin a position, transfer price negotiations can take a third of their time. By decreasing concessions and therefore, decrease time spent on transfer price negotiations, managers can attend to value added activities.

\subsection{Limitations and future research}

The results of our study should be interpreted within the context of the limitations. The graduate students who volunteered to participate came from one mid-Atlantic university. Therefore, these results may not be representatives of other regions and cultures. Another possible limitation is because the negotiation position is based on a hypothetical scenario and only the initial transfer price is captured. We cannot be fully certain that the same behavior will be repeated in a business setting.

As identified by Douglas et al. (2001), Douglas and Wier (2000), and Singhapakdi, Vitell and Kraft (1996), the influence of moral intensity needs to be considered when examining ethical behavior. Jones (1991, p. 379) determined the multidimensional construct moral intensity consists of six areas: "Magnitude of Consequences, Social Consensus, Probability of Effect, Temporal Immediacy, Proximity, and Concentration of Effect." Individuals assess situations using these characteristic and when combined, individuals may surpass an "ethical threshold" that will cause them to access higher moral decision reasoning. As suggested in Douglas and Wier's (2000) obiter dicta, some managers may not feel necessary to access their higher level of moral reasoning when making decisions. Accordingly, some participants may have used a higher level or moral reasoning than others and therefore affecting the transfer price selected.

These limitations lead to areas of future research in transfer pricing negotiations. Future research in this area could provide additional evidence of the effects of EP by examining concessions throughout the negotiation processes and the final price as opposed to focusing on the initial position. In addition, future research could identify how moral intensity effects transfer price negotiations. 


\section{References}

Autrey, R. L., \& Bova, F. (2012). Gray markets and multinational transfer pricing. The Accounting Review, Vol. 87, pp. 393-421. http://aaapubs.org/doi/full/10.2308/accr-10199

Baldenius, T. (2000). Intrafirm trade, bargaining power, and specific investments. Review of Accounting Studies, Vol. 5, pp. 27-56. http://dx.doi.org/10.1023/A\%3A1009612901910

Baldenius, T., Reichelstein, S., \& Sahay, S. A. (1996). Negotiated versus cost-based transfer pricing. Review of Accounting Studies, Vol. 4, pp. 67-91. http://dx.doi.org/10.1023/A\%3A1009638001487

Bazerman, M. H., \& Moore, D. A. (2009). Judgment in managerial decision making. Hoboken, NJ: Wiley.

Bear, J. B., \& Babcock, L. (2012). Negotiation topic as a moderator of gender differences in negotiation. Psychological Science, Vol. 23, pp. 743-744. http://dx.doi.org/10.1177/0956797612442393

Bowles, H. R., Babcock, L., \& McGinn, K. L. (2005). Constraints and triggers: Situational mechanics of gender in negotiation. Journal of Personality and Social Psychology, Vol. 89, pp. 951-965. http://psycnet.apa.org/doi/10.1037/0022-3514.89.6.951

Bok, S. (1978). Lying: Moral choice in public and private life. New York, NY: Pantheon Books.

Carr, A. (1968). Is business bluffing ethical? Harvard Business Review, Vol. 46, pp. 143-153.

Chang, L., Cheng, M., \& Trotman, K. T. (2008). The effect of framing and negotiation partner's objective on judgments about negotiated transfer prices. Accounting, Organizations and Society, Vol. 33, pp. 704-717. http://dx.doi.org/10.1016/j.aos.2008.01.002

Davis, M. A., Andersen, M. G., \& Curtis, M. B. (2001). Measuring ethical ideology in business ethics: A critical analysis of the ethics position questionnaire. Journal of Business Ethics, Vol. 32, pp. 35-53. http://dx.doi.org/10.1023/A\%3A1010701417165

Dembinski, P. H. (2006). Ethical aspects of transfer pricing. Finance and Bien Commun, Vol. 24, pp. 78-89. http://dx.doi.org/10.3917/fbc.024.0078

Donaldson, T., \& Wehane, P. H. (1996). Ethical issues in business. Upper Saddle River, NJ: Prentice-Hall, Inc.

Douglas, P. C., \& Wier, B. (2000). Integrating ethical dimensions into a model of budgetary slack creation. Journal of Business Ethics, Vol. 28, pp. 267-277. http://dx.doi.org/10.1023/A\%3A1006241902011

Douglas, P. C., Davidson, R. A., \& Schwartz, B. N. (2001). The effect of organizational culture and ethical orientation on accountants' ethical judgments. Journal of Business Ethics, Vol. 34, pp. 101-121. http://dx.doi.org/10.1023/A\%3A1012261900281

Eccles, R. (1985). The transfer pricing problem: A theory for practice. Lexington: Lexington Books.

Edlin, A. S., \& Reichelstein, S. (1995). Specific investment under negotiated transfer pricing: An efficiency result. The Accounting Review, Vol. 70, pp. 275-291.

Einhorn, H. J., \& Hogarth, R. M. (1981). Behavioral decision theory: Processes of judgment and choice. Annual Review of Psychology, Vol. 32, pp. 53-88. http://dx.doi.org/10.1146/annurev.ps.32.020181.000413

Eisenhardt, K. M. (1989). Agency theory: An assessment and review. The Academy of Management Review, Vol. 14, pp. 57-74. http://dx.doi.org/ 10.5465/AMR.1989.4279003

Fisher, J., Fredrickson, J. R., \& Peffer, S. A. (2002). The effect of information asymmetry on negotiated budgets: An empirical investigation. Accounting, Organizations and Society, Vol. 27, pp. 27-43. http://dx.doi.org/10.1016/S0361-3682(01)00046-0

Forsyth, D. (1980). A taxonomy of ethical ideologies. Journal of Personality and Social Psychology, Vol. 39, pp. 175-184. http://dx.doi.org/10.1037/0022-3514.39.1.175

Forsyth, D. (1981). Moral judgment: The influence of ethical ideology. Personality and Social Psychology Bulletin, Vol. 7, pp. 218-223. http://dx.doi.org/10.1177/014616728172006

Forsyth, D., \& Pope, W. R. (1984). Ethical ideology and judgments of social psychological research: Multidimensional analysis. Journal of Personality and Social Psychology, Vol. 46, pp. 1365-1375. http://dx.doi.org/10.1037/0022-3514.46.6.1365

Fudenberg, D., \& Tirole, J. (1983). Sequential bargaining with incomplete information. Review of Economic Studies, Vol. 50, pp. 221-247. http://dx.doi.org/10.2307/2297414

Ghee-Soon Lim, S., \& Murnighan, J. K. (1994). Phases, deadlines and the bargaining process. Organization Behavior and Human Decision Processes, Vol. 58, pp. 153-171. http://dx.doi.org/10.1006/obhd.1994.1032 
Ghosh, D. (2000). Complementary arrangements of organizational factors and outcomes of negotiated transfer price. Accounting, Organizations and Society, Vol. 25, pp. 661-682. http://dx.doi.org/10.1016/S0361-3682(99)00060-4

Greenfield, Jr., A. C., Norman, C. S., \& Wier, B. (2008). The effect of ethical orientation and professional commitment on earnings management behavior. Journal of Business Ethics, Vol. 83, pp. 419-434. http://dx.doi.org/10.1007/s10551-007-9629-4

Haake, C. J., \& Martini, J. T. (2012). Negotiating Transfer Prices. Group Decision and Negotiation, Vol. 22, pp. 657-680. http://dx.doi.org/10.1007/s10726-012-9286-6

Harrell, A., \& Harrison, P. (1994). An incentive to shirk, privately-held information and managers' project evaluation decisions. Accounting Organizations and Society, Vol. 19, pp. 569-577. http://dx.doi.org/10.1016/0361-3682(94)90024-8

Horngren, C. T., Datar, S. M., \& Foster, G. (2011). Cost Accounting: A Managerial Emphasis. Upper Saddle River, NJ: Pearson Prentice Hall.

Jones, T. M. (1991). Ethical decision making by individuals in organizations: An issue-contingent model. The Academy of Management Review, Vol. 16, pp. 366-395.

Kachelmeier, S. J., \& Towry, K. L. (2002). Negotiated transfer pricing: Is fairness easier said than done? The Accounting Review, Vol. 77, pp. 571-593. http://dx.doi.org/10.2308/accr.2002.77.3.571

Kennan, J., \& Wilson, R. (1993). Bargaining with private information. American Economic Association, Vol. 31, pp. 45-104.

Libby, R., Bloomfield, R., \& Nelson, M. W. (2002). Experimental research in financial accounting. Accounting Organizations and Society, Vol. 27, pp. 775-810. http://dx.doi.org/10.1016/S0361-3682(01)00011-3

Luft, J. L., \& Libby, R. (1997). Profit comparisons, market prices and managers' judgments about negotiated transfer prices. The Accounting Review, Vol. 72, pp. 217-229.

Nasir, N. E., Sallem, N. R., \& Othman, R. (2012). Factors influencing ethical ideology among accounting students and practitioners. IEEE Colliquium on Humanties, Science and Engineering Research (CHUSER 2012), (pp. 578-583). Kota Kinabalu, Sabah, Malaysia. http://dx.doi.org/10.1109/CHUSER.2012.6504379

Neale, M. A., \& Baserman, M. H. (1991). Cognition and Rationality in Negotiation. New York, NY: The Free Press.

Pfeiffer, T., Schiller, U., \& Wagner, J. (2011). Cost-based transfer pricing. Review of Accounting Studies, Vol. 16, pp. 219-246. http://dx.doi.org/10.1007/s11142-011-9140-0

Podsakoff, P. M., MacKenzie, S. B., Lee, J. Y., \& Podsakoff, N. P. (2003). Common method biases in behavioral research: a critical review of literature and recommended remedies. Journal of Applied Psychology, Vol. 88, pp. 879-903. http://dx.doi.org/10.1016/j.jretai.2012.08.001

Pruitt, D. G. (1981). Negotiation Behavior. London: Academic Press, Inc.

Quintelier, K. J., \& Fessler, D. M. (2012). Varying versions of moral relativism: The philosophy and psychology of normative relativism. Biology and Philosophy, Vol. 27, pp. 95-113. http://dx.doi.org/10.1007/s10539-011-9270-6

Rubinstein, A. (1991). Comments on interpretation of game theory. Econometrica, Vol. 59, pp. 909-924. http://dx.doi.org/10.2307/2938166

Ritov, I. (1996). Anchoring in simulated competitive market negotiation. Organization Behavior and Human Decision Procoesses, Vol. 67, pp. 16-25. http://dx.doi.org/10.1006/obhd.1996.0062

Sahay, S. A. (2003). Transfer pricing based on actual cost. Journal of Management Accounting, Vol. 15, pp. 177-192. http://dx.doi.org/10.2308/jmar.2003.15.1.177

Singhapakdi, A., Vitell, S. J., \& Kraft, K. L. (1996). Moral intensity and ethical decision-making of marketing research. Journal of Business Research, Vol. 36, pp. 245-255. http://dx.doi.org/10.1016/0148-2963(95)00155-7

Stevens, D. E. (2002). The effects of reputation and ethics on budgetary slack. Journal of Management Accounting, Vol. 14, pp. 153-171. http://dx.doi.org/10.2308/jmar.2002.14.1.153

Thompson, L., \& Lowenstein, G. (1992). Egocentric interpretations of fairness and interpersonal conflict. Organizational Behavior and Human Decision Processes, Vol. 51, pp. 176-197. http://dx.doi.org/10.1016/0749-5978(92)90010-5 